\title{
Effect of Integrated Nutrient Management on Growth and Yield of Kalmegh (Andrographis paniculata Wall. Ex. Nees.): A Review
}

\author{
R. Praveenakumar ${ }^{1 *}$, Manjuprakash ${ }^{2}$ and H.G. Hanumathraya ${ }^{1}$ \\ ${ }^{1}$ Department of Horticulture, UAS, GKVK, Bengaluru, Karnataka, India \\ ${ }^{2}$ Department of Agricultural Extension, UAS, GKVK, Bengaluru, Karnataka, India \\ *Corresponding author
}

\section{Key words \\ Kalmegh, Organic manures, Inorganic manure, Bio fertilizers, Yield \\ Article Info \\ Accepted: \\ 18 August 2018 \\ Available Online: \\ 10 September 2018}

\section{A B S T R A C T}

Andrographis paniculata is also known as "Rice bitters" in West Indies and "King of bitters" or "Chiretta" in England. The fresh and dried leaves of Kalmegh and the juice extracted from the herb are official drugs in Indian pharmacopoeia. The whole herb is the source of several diterpinoids of which the bitter water-soluble lactone is important and is distributed all over the plant body in different proportions. Kalmegh (King of bitters), is used both in Ayurvedic and Unani System of medicines for immunological, antibacterial, anti-inflammatory, antithrombotic and hepatoprotective properties, using of different organic manure (FYM, Vermicompost, Green Manure, Poultry And Sheep Manure, Night Soil etc,) inorganic manure (Macro and Micro nutrients) and Bio fertilizers (rhizobium, VAM, Azotobacter, Azospirillum, P Solubilizing Bacteria) have assumed great importance for sustainable production and for maintaining soil health. In spite of supplying macro and micro-nutrients to the crop it also enhance physical, chemical and biological properties of the soil, which leads to good crop production. The advantage of combining inorganic and organic sources of nutrients generally results in better use of each component which is responsible for crop growth and development. In this paper, the literatures pertaining to the different aspects of integrated nutrient management are reviewed.

\section{Introduction}

Kalmegh (Andrographis paniculata Wall. Ex. Nees.) belongs to family Acanthaceae is one of the nineteen species of the genus Andrographis which is indigenous to India and has been used in Indian systems of medicine since time immemorial. Kalmegh is a bitter annual (perennial, if maintained) herb, erect, $50 \mathrm{~cm}$ to $1 \mathrm{~m}$ in height, stem quadrangular, much branched; leaves opposite, short petioled; flowers in racemes. Fruit capsule, linear, oblong or elliptic; seeds about 12 in number, subquadrate, brownish or creamy yellow. Kalmegh (King of bitters), is used both in Ayurvedic and Unani System of medicines for immunological, antibacterial, antiinflammatory, antithrombotic and hepatoprotective properties. Andrographolide is an interesting pharmacophore with anticancer and immunomodulatory, antipyretic, antihepatotoxic, antihistamic, analgesic, antibacterial, antifertility and immunosuppressive, dysentery, diarrhea, enteritis, fever, cough, sore throat, tonsillitis, bronchitis, arthralgia, menstrual and 
postpartum haematometra; hypertention and snake bite activities and hence has the potential to be developed as an anticancer chemotherapeutic agent as well. Kalmegh forms the principle ingredient of household medicine called "Alui", extensively used in West Bengal. Common ayurvedic drugs are "Kalmeghasava" and "Kalmeghnamayas Haub" (Sanjutha et al., 2008). There is a growing concern about adverse effect of use of chemical fertilizers and chemical pesticides. Understanding the ill effects of such chemicals, it was deliberated to use organic manures (farmyard manure, oil cakes and vermicompost) and biofertilizers. The interactive advantage of combining inorganic and organic sources of nutrients generally results in better use of each component (Manna et al., 2005).

\section{Effect of integrated nutrient management on growth parameters and yield parameter of kalmegh}

Makwana et al., (2009) tested different organic manures and spacing on yield of Kalmegh-Panchang under middle Gujarat conditions. They observed that the growth attributes such as plant height $(71.36 \mathrm{~cm})$ and plant breadth (23.89) at harvest were significantly higher under treatment $30 \mathrm{~cm} \times$ $45 \mathrm{~cm}$. They recorded the highest fresh $(10335 \mathrm{~kg} / \mathrm{ha})$ and dry yield $(4375 \mathrm{~kg} / \mathrm{ha})$ of kalmegh under treatment of $30 \mathrm{~cm} \times 45 \mathrm{~cm}$.

Ramesh et al., (2011) studied the effect of interactive influence of organic and inorganic fertilizers on the growth and yield of kalmegh.

They found that combined application of organic and inorganic fertilizers produce better growth and yield parameters. Application of VAM and its combination with added inorganic nutrients enhanced andrographolide content in kalmegh
Ram et al., (2008) worked on spacing and organics on growth and herbage yield of kalmegh. They observed that the maximum plant growth viz., plant spread, number of primary and secondary branches and number of leaves/plant was found at wider spacing $(30 \times 40 \mathrm{~cm})$ and concluded that the maximum fresh and dry herbage yield (94.18 $\mathrm{q} /$ ha and $54.33 \mathrm{q} / \mathrm{ha}$ ) was obtained at closer spacing $(30 \times 30 \mathrm{~cm})$. Interaction effect due to spacing and various sources of organics was found non-significant.

Sanjutha et al., (2008) studied integrated nutrient management in kalmegh. They conducted experiment in Randomized Block Design (RBD) with 12 treatments replicated thrice at TNAU Coimbatore, India. They found that application of FYM @ 15 t/ha + NPK @75:75:50 kg/ha + Panchyagavya @3 $\%$ foliar spray recorded highest parameters, nutrient uptake, yield and andrographolide content.

Ram et al., (2008) conducted an experiment on effect of spacing and organics on growth and herbage yield of kalmegh (Andrographis paniculata Wall. Ex. Nees.). The results indicated that the maximum plant growth viz., plant spread, number of primary and secondary branches and number of leaves per plant have been found at wider spacing (30 x $40 \mathrm{~cm}$ ) and due to use of the application of FYM prolong to 50 per cent flowering (only 2 days) compared to control. The maximum fresh and dry herbage yield (94.18 q/ha and $54.33 \mathrm{q} / \mathrm{ha}$ ) was obtained at closer spacing (30 x $30 \mathrm{~cm}$ ).

Hemalatha and Suresh (2012) studied impact of integrated nutrients on growth and yield of kalmegh. They observed the highest plant height $(56.54 \mathrm{~cm} /$ plant $)$, number of branches (22.65/plant) and number of leaves (41.40/plant), leaf area (128.34 cm 2 /plant), dry biomass $(2.639 \mathrm{t} / \mathrm{ha})$ and fresh herbage 
$(1392.22 \mathrm{~kg} / \mathrm{ha})$ and alkaloid yield $(0.739 \%)$ in the treatment containing $15 \mathrm{t} \mathrm{FYM/ha} \mathrm{+}$ 45:25:25 kg NPK/ha +1 kg Azospirillum/ha.

Patidar et al., (2011) conducted research on biochemical constituents in kalmegh under various row spacings and nitrogen levels, at department of plant physiology, College of Agriculture 24 Jawaharlal Nehru krishi Vishwa Vidyalaya, Jabalpur M.P. India. They took three row spacings viz., 15,30 and 45 $\mathrm{cm}$ and five nitrogen levels viz., 0, 40, 60, 80 and $100 \mathrm{~kg} / \mathrm{ha}$ and found that $30 \mathrm{~cm}$ row spacing with $80 \mathrm{~kg} \mathrm{~N}$ level and their combination possessed the highest content of biochemical constituents.

Singh et al., (2011) conducted an experiment on growth behaviour, biomass and diterpenoid lactone production in kalmegh strains at different population densities and found that growing of kalmegh strain CIMAP-3 and planting at a closer spacing of $30 \times$ $15 \mathrm{~cm}$ accommodating 2,22,222 plants/ha is suggested for obtaining maximum dry biomass and diterpenoid lactones yield under the subtropical climate of North India.

Dakhane and Nandkar (2012) studied the influence of nutrients on growth and medicinal content of Andrographis paniculata wall. Ex. Nees. And found that the highest herbage yield was obtained in treatment 200:140:15:90:60:25:44:20:14 kg /ha N, P, K, $\mathrm{Ca}, \mathrm{Mg}, \mathrm{Fe}, \mathrm{Mn}, \mathrm{Zn}, \mathrm{Cu}$, respectively.

The higher yield obtained in Kalmegh due to integration of inorganic fertilizers, bio fertilizers and organic manures could be due to the higher yield attributing characters like root length and girth, higher dry matter production by higher supply of nutrients, favorable physical and biological environment with increased organic carbon in the soil leading to better root activity and nutrient uptake. As Kalmegh is a root crop, improvement of soil physical environment might be helped in better development of root development.

\section{References}

Dakhane VP, and Nandkar PB. Influence of nutrients on growth and medicinal content of Andrographis paniculata Wall. Ex. Nees. Bionanofronter, 2012; $52-11$.

Hemalatha P. and Suresh J. Impact of integrated nutrients on growth and yield of kalmegh. Int. J. Agril. Sci., 2012; 8 (1): $168-170$.

Makwana PD, Patel J.J., and Patel HK. Effect of different organic manures and spacing on yield and yield attiributes of kalmegh-panchang (Andrographis paniculata Wall. Ex. Nees.) under middle Gujarat conditions. Int. $\mathrm{J} . \mathrm{Pl}$. Sci., 2009: 5 (1): 30-32.

Manna MC, Swarup AM, Wanjari RH, Ravankar HN, Mishra B, Saha MN, Singh YV, Sahi DK, Sarap PA et al., Long-term effect of fertilizers and manure application on soil organic carbon storage, soil quality and yield sustainability under sub-humid and semi-arid tropical India. Field Crop Research 2005; 93: 264 -280.

Patidar S, Gontia AS, Upadhyay and Nayak PS. Biochemical constituents in kalmegh (Andrographis paniculata Nees.) under various row spacings and nitrogen levels. World Applied Sciences Journal, 2011; 15 (8): 1095-1099.

Ram D, Chandra R. and Kumar B. Effect of spacing and organics on growth and herbage yield of kalmegh (Andrographis paniculata Wall. Ex. Nees). Progressive Horticulture, 2008; 40 (1): 69-73.

Ramesh G, Shivanna M.B., and Santa RA. Interactive influence of organic manures and inorganic fertilizers on growth and 
yield of kalmegh. (Andrographis paniculata Nees). Int. Res. J. Pl. Sci., (2011); 2(1): 16-21.

Sanjutha S Subramanian S Rani I. and Maheswari J. Integrated nutrient management in Andrographis paniculata. Res. J. Agri. and Biological Sci., 2008; 4 (2): 141-145.
Singh SP. Effect of organic, inorganic and bio-fertilizer Azospirillum on growth and yield attributing characters of turmeric (Curcuma longa L.) cv. Rajendra Sonia. The Asian Journal of Horticulture, 2011; 6 (1): 16-18.

\section{How to cite this article:}

Praveenakumar, R., Manjuprakash and Hanumathraya, H.G. 2018. Effect of Integrated Nutrient Management on Growth and Yield of Kalmegh (Andrographis paniculata Wall. Ex. Nees.): A Review. Int.J.Curr.Microbiol.App.Sci. 7(09): 2616-2619. doi: https://doi.org/10.20546/ijcmas.2018.709.325 